\title{
A Traumatic Case of the Scrotum by Firearm and with a Dramatic Evolution
}

\author{
Dje Koffi, Avion Kouassi Patrice*, Akassimadou N’Diamoi, Aguia Brice Romuald, \\ Zouhan Fredy, Alloka Venance \\ Urology Department of the University Hospital Center (CHU) of Bouaké, Bouaké, Ivory Coast \\ Email:Djekoffi1958@gmail.com, *avionkouassi@yahoo.fr, ndiamoi74@gmail.com, donbricofr@gmail.com, \\ docteurzouan@gmail.com, venancedagotchaka@gmail.com
}

How to cite this paper: Koffi, D., Patrice, A.K., N’Diamoi, A., Romuald, A.B., Fredy, Z. and Venance, A. (2020) A Traumatic Case of the Scrotum by Firearm and with a Dramatic Evolution. Open Journal of Urology, 10, 79-83.

https://doi.org/10.4236/oju.2020.104009

Received: December 26, 2019

Accepted: February 25, 2020

Published: February 28, 2020

Copyright $\odot 2020$ by author(s) and Scientific Research Publishing Inc. This work is licensed under the Creative Commons Attribution International License (CC BY 4.0).

http://creativecommons.org/licenses/by/4.0/

\begin{abstract}
Gunshot wound is rare on the testicles and involves the patient's reproductive function. The authors report a case of open gunshot wound trauma to the testicles in a 45-year-old patient with no particular information, except, living with two women and eight children. Emergency sharing noted a fracture of the right testicle with damage of the cord components. After the surgery, the left testicle was necrotic, so a left orchiectomy was performed. The aftermaths of this second surgery were simple. However, the management of this hunting accident resulted in castration, which poses the problem of the patient's sexuality.
\end{abstract}

\section{Keywords}

Bursa Trauma, Orchiectomy, Testicular Necrosis

\section{Introduction}

Gunshot wounds, defined as any wound produced on the human body by the approach or impact of a firearm, are generally rare, whether they are wounds caused by weapons of war or projectiles in a civilian context [1]. Such gunshot wounds are much rarer on the testicle and involve the patient's reproductive function [2].

This is a report of gunshot wound to the testicles.

\section{Observation}

He is a 45-year-old patient, a hunter, with no particular information, except, living with 2 women and 8 children all alive and in apparent good health. $\mathrm{He}$ 
was admitted to the surgical emergency room of Bouaké University Hospital Center for open gun trauma after a hunting accident that occurred six hours before his arrival in our center.

The patient had inadvertently pulled the trigger of his shotgun while using a buckshot. Physical examination had shown a dilapidated and hemorrhagic wound of the scrotum exposing the fractured right testicle with no exit orifice (Figure 1), the contralateral testicle was difficult to examine. There was swelling of the penis (Figure 2). There was no urethroorrhage, urine retention, or hematuria.

Radiography of the pelvis had shown numerous rounded foreign bodies reminiscent of buckshot on the testicles with dispersion of some projectiles in the surrounding tissues. The bony frame was free of any fracture lesions. Surgical exploration had noted the presence of foreign bodies (Figure 3 and Figure 4), the right testicle fractured with lesion of the spermatic cord vessels, the contralateral testicle was macroscopically healthy. It was trimmed with a right orchiectomy.

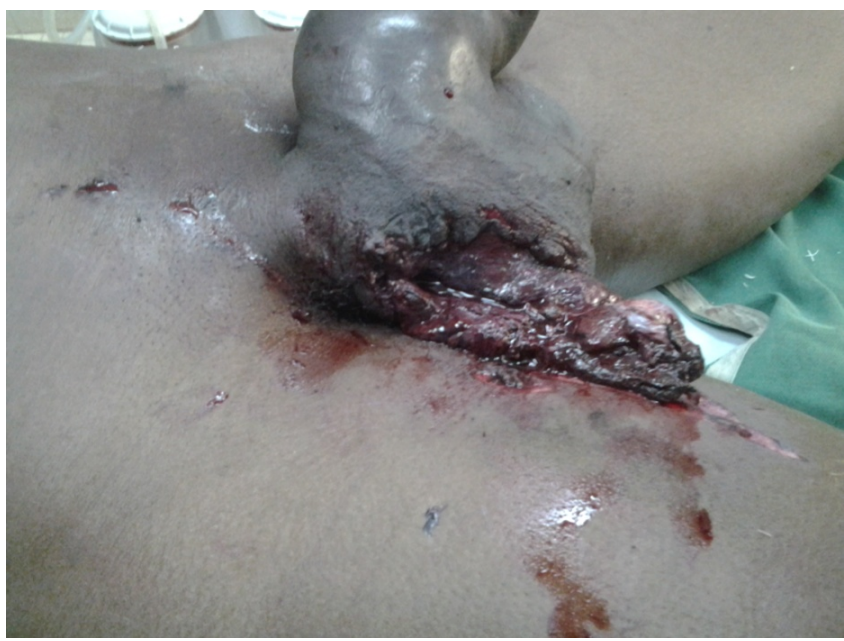

Figure 1. Deteriorating scrotal wound exposing the right testicle.

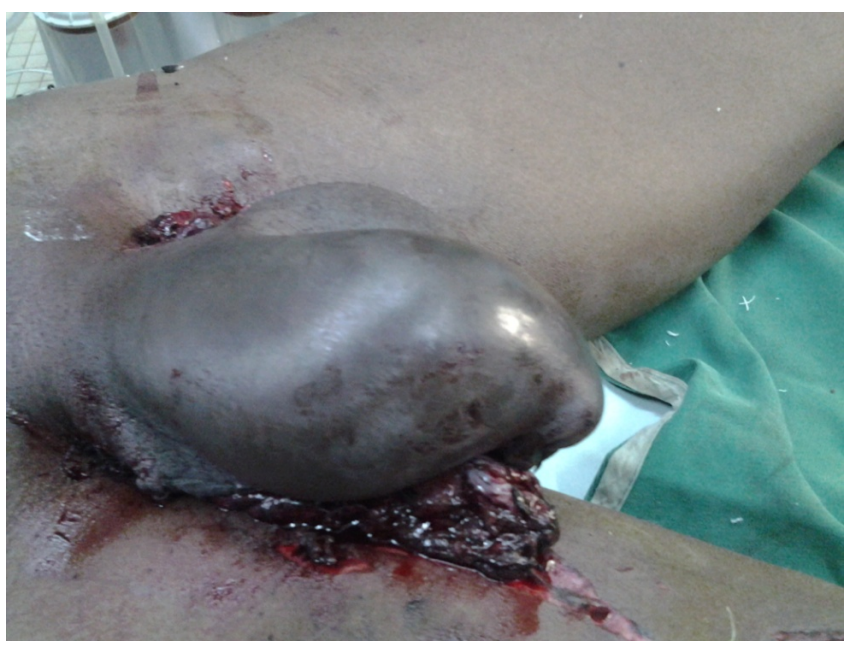

Figure 2. Voluminous swelling of the penis. 


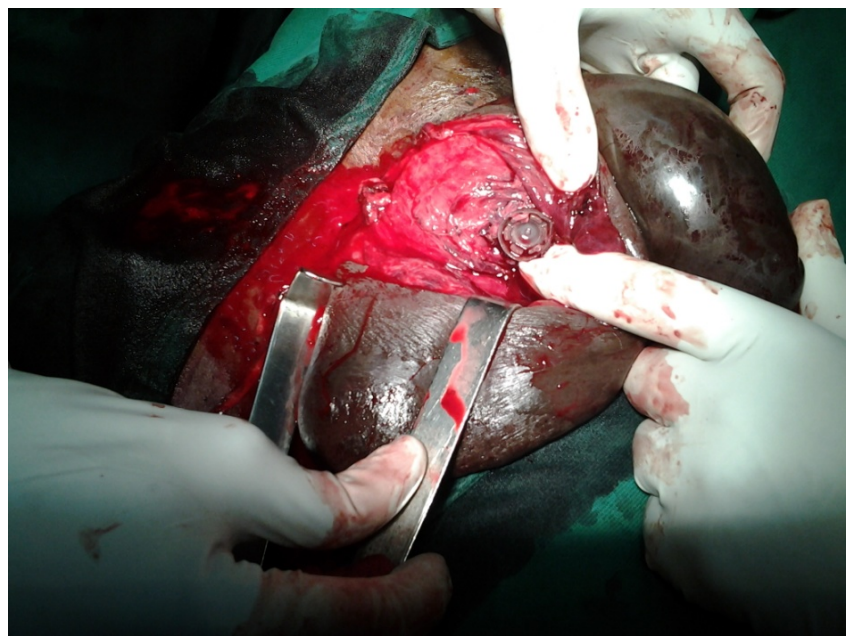

Figure 3. Intraoperative view of the foreign body.

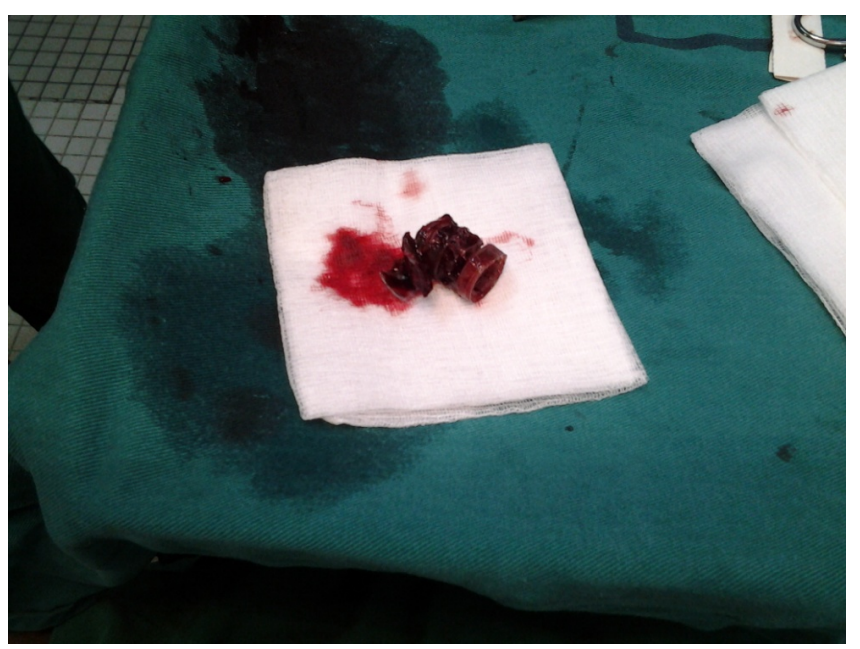

Figure 4. The foreign body after removal.

Antibiotics and anti-inflammatory medicines were introduced postoperatively. The postoperative period was marked by necrosis of the remaining testicles even (7) days after the first orchidectomy which was treated by a left orchidectomy. After a 4-month follow-up, the patient did not have an erection.

\section{Discussion}

Gunshot wound trauma on testicles is an uncommon accident. The different series of publications concern a small number of patients; case [3] reports the largest series (64 cases in 20 years) and Barthelemy (33 cases in 10 years) [4]. Other publications concern a certain number of patients, between 6 cases for Mac Dermott [5] and 53 cases for Altarac [6]. Traumas are even rarer than when they are caused by firearms [7]. This rarity has been noted by Bah et al. ( 6 cases in 4 years) [8], Odzébe et al. (2 cases in 6 years) [9], Dekou et al. (8 cases in 6 years) [10].

Our only case observed in 4 years confirms this extremely rare cause of testicle 
trauma.

The mechanism of injury in firearm wounds makes it possible to distinguish between civilian practice wounds, and war injured which are more severe and extended [11]. In this case, the wound was in a civilian context. These accidents are due to a lack of control over weapons and their ammunitions, either through acts of torture or revenge in the case of Mianne et al. [7].

We can explain the occurrence of trauma in our patient by the fact that in our regions and villages, hunting weapons are not conventional, because they are manufactured by the owner himself. The average age of the traumas of the testicles varies between 10 and 37 years [4] [8] [9] [10] [12]. For these authors, this young age is explained by the fact that this is the active layer of the population, and therefore more exposed to trauma. In our case, the patient is 45 -year-old and in addition to the reasons reported in the literature review, his profession could also expose him to these types of trauma.

For some authors, patients consult early for open trauma (2) and this could be explained by the spectacular appearance of the lesions. However, despite the open trauma noted in our case, the patient consulted more than six hours after the trauma.

This delay in consultation could be explained by the fact that the accident occurred while hunting at night. The lack of transportation from countryside to the city at late hours is a factor lengthens the consultation time.

From a therapeutic point of view, the treatment of external genital lesions with firearm poses several problems: 1) forensic matters, because testicular lesions involve the prognosis of the patient's reproduction, 2) the urethral lesions that may be complicated by shrinkage, and 3) in some cases, sexual impotence due to damage of erectile nerves [13]. In addition to these three problems, there are all the complications of open trauma, in this case infections. To deal with infectious complications, emergency wound trimming is the first stage of treatment. It allows a precise inventory of the lesions to be made, a complete excision of the necrotic tissue and an abundant washing of the remaining tissue [7] [11].

Testicular injuries should be managed according to the Organ injury scaling committee (OIS) of the American association for the surgery of trauma (AAST) [14]. It recommends orchiectomy for grade V, conservative treatment for large I and III, and finally surgical surveillance or exploration for large I. In our case the attitude we have adopted is in line with that recommended in the literature. However, the postoperative period was complicated by the necrosis of the contralateral testicle. These could be explained on the one hand by microscopic lesions of the elements of the cord of the left testicle which would have led to ischemia and then testicular necrosis. It is therefore advisable to inform any patient with open trauma to the scrotum of the risks of possible castration and the resulting consequences. To this end, the possibility of sperm storage should be discussed with the patient according to Bah et al. [8].

For our patient this option had been proposed to him, but he did not consider 
it opportune, as he was already a father of 8 children, the possibility of sperm conservation for medically assisted procreation was of less importance.

\section{Conclusion}

Gunshot wounds are rare. They are severe and are prognostic for reproduction. The patient must therefore be warned of possible castration and the consequences of this.

\section{Conflicts of Interest}

The authors declare no conflicts of interest regarding the publication of this paper.

\section{References}

[1] Ceccaldi, P.F. (1969) La criminalistique. Presses universitaires de France, Paris.

[2] Diao, B., Ndoye, K., Fall, P.A., et al. (2007) Les traumatismes des bourses: A propos de 14 observations. African Journal of Urology, 13, 151-756.

[3] Cass, A.S. and Luyenberg, M. (1991) Testicular Injuries. Urology, 37, 528-553. https://doi.org/10.1016/0090-4295(91)80317-Z

[4] Barthelemy, Y., Delmas, V., Villers, A., et al. (1992) Traumatisme des bourses à propos de 33 cas. Progrès en Urologie, 15, 628-634.

[5] Mac Dermott, J.P., Gray, B.K. and Hamilton Stewart, B.K. (1988) Traumatic Rupture of the Testis. British Journal of Urology, 62, 179-181. https://doi.org/10.1111/j.1464-410X.1988.tb04303.x

[6] Altarac, S. (1994) Management of 53 Cases of Testicular Trauma. European Urology, 25, 119-123. https://doi.org/10.1159/000475264

[7] Mianne, D., Guillotreau, J. and Sergent, H. (1997) Les plaies périnéales en pratique de guerre. Annales d Urologie (Paris), 31, 303.

[8] Bah, I.A., Diallo, B., N'doye, A.K., et al. (2006) Les lésions des organes génitaux externes par arme à feu. A propos de six observations à l'hôpital A. le Dactec, Dakar, Senegal.

[9] Odzébe, A.W.S., Bouya, P.A. and Banga, M.R. (2009) Les traumatismes des bourses. African Journal of Urology, 15, 130-134. https://doi.org/10.1007/s12301-009-0022-7

[10] Dekou, A., Konan, P.G., Kouame, B., et al. (2008) Les traumatismes de l'appareil génito-urinaire: aspects épidémiologiques et lésionnels. African Journal of Urolog, 4, 105-113. https://doi.org/10.1007/s12301-008-0001-4

[11] Pons, F., Rigal, S. and Dupeyron, C. (1997) Les plaies abdomino-pelvi-fessières de guerre. Principes de traitement. Annales d Urologie (Paris), 31, 294.

[12] Culty, T. and Ravery, V. (2004) Traumatismes scrotaux: Stratégie de prise en charge. Annales d Urologie, 40, 117-125.

https://doi.org/10.1016/j.anuro.2006.01.008

[13] Gorki, K., Oukheira, H. and Draoui, M.I. (1987) Les plaies de l'urètre par projectiles de guerre. A propos de 19 cas. Acta Urologica Belgica, 55, 625.

[14] Mohr, A.M., Pham, A.M., Lavery, R.F., et al. (2003) Management of Trauma to the Male External Genitalia: The Use Fullness of American Association for the Surgery of Trauma Organ Injury Scales. Journal of Urology, 170, 2311-2315. https://doi.org/10.1097/01.ju.0000089241.71369.fa 